BULLETIN Bulletin hispanique

HISPANIQUE Université Michel de Montaigne Bordeaux

115-1 | 2013

Poésie et société en Espagne : 1650-1750

\title{
La epístola poética en el bajo barroco
}

impreso y sociabilidad

\section{Pedro Ruiz Pérez}

\section{(2) OpenEdition}

Journals

Edición electrónica

URL: http://journals.openedition.org/bulletinhispanique/2459

DOI: 10.4000/bulletinhispanique.2459

ISSN: 1775-3821

Editor

Presses universitaires de Bordeaux

\section{Edición impresa}

Fecha de publicación: 1 junio 2013

Paginación: 221-250

ISBN: 978-2-86781-898-1

ISSN: 0007-4640

Referencia electrónica

Pedro Ruiz Pérez, «La epístola poética en el bajo barroco », Bulletin hispanique [En línea], 115-1 | 2013,

Publicado el 01 junio 2016, consultado el 30 abril 2019. URL : http://journals.openedition.org/

bulletinhispanique/2459; DOI : 10.4000/bulletinhispanique.2459 


\title{
La epístola poética en el bajo barroco: impreso y sociabilidad ${ }^{1}$
}

\author{
Pedro Ruiz Pérez \\ Universidad de Córdoba - España
}

Les changements dans le contenu de l'épittre en vers montrent la transformation des valeurs et des rapports sociaux tout comme le font également les nouvelles formes pragmatiques et stylistiques qui configurent le genre. Son apparition dans le livre imprimé de poésie est considérée comme un des axes du changement, reflet de nouvelles pratiques de lecture et de la sociabilité qui les accompagnent. L'analyse portera sur les textes de Solis et de Benegasi.

Mots clés: épître poétique, baroque tardif, Antonio de Solís, José Joaquín Benegasi, sociabilité, édition.

Los cambios en los contenidos de la epistola en verso dan cuenta de la transformación en los valores y relaciones sociales, como también lo hacen las nuevas modalidades pragmáticas y estilísticas que conforman el género. Su inserción en el libro de poesía impreso se plantea como uno de los ejes del cambio, reflejo de nuevos usos lectores y de la sociabilidad a que acompañan. Se analiza a partir de los textos de Solís y Benegasi.

Palabras claves: epístola poética, bajo barroco, Antonio de Solís, José Joaquín Benegasi, sociabilidad, edición.

The changes in the content of the epistle in verse show the transformation of values and social relations, as do the new pragmatic and stylistic forms in the genre. Its appearance in the printed book of poetry is seen as one of the lines of change, reflecting the new reading uses and the sociability that accompany them. The analysis will focus upon the texts of Solis and Benegasi.

Keywords: poetic epistle, low Baroque, Antonio de Solís, José Joaquín Benegasi, sociability, editing.

1. El presente trabajo se inscribe en el proyecto de investigación Poesía hispánica en el bajo barroco (Repertorio, edición, historia), FFI2008-24102 del Plan Nacional de Investigación Científica, Desarrollo e Innovación Tecnológica.

Bulletin Hispanique, Tome 115, n 1 - juin 2013 - p. 221-250. 


\section{EL LUGAR DE LOS GÉNEROS NEOCLÁSICOS}

Con esta feliz acuñación Elias L. Rivers agrupó las innovaciones introducidas por Garcilaso en la tercera etapa de su trayectoria poética ${ }^{2}$. En cercanía a sus modelos grecolatinos, la oda, las elegías, la epístola y las églogas abrían un nuevo espacio poético ${ }^{3}$, apenas transitado en la poesía hispana y siempre con diferencias sustanciales, como las que establecen las cartas octosilábicas o la pastoral rústica. La diferencia, más que temática, era tonal, más prosódica que estrictamente métrica, con una distancia respecto a lo precedente relacionada con una nueva posición del sujeto poético y un cambio en su sentimentalidad. El desplazamiento a una objetividad de grados diversos, representada en una importante aparición de la tercera persona, es una de las manifestaciones más evidentes y, al tiempo, más profundas y trascendentes. En gran medida, la poesía de finales del siglo XVI recorrerá ese camino, con no poco peso de la renovación suscitada en el romancero, en su vertiente artística; Góngora, finalmente, llevará esta deriva a su máxima expresión, tanto en sus escandalosas fábulas narrativas como en el no menos desestabilizador manejo de lo burlesco. Sin embargo, coincidiendo con la muerte del cordobés, el repliegue de la poética barroca en torno al confesionalismo lopesco y la expresividad quevedesca vendría a sancionar el firme arraigo de la misma en el humus de la poética petrarquista, de la que se seguía nutriendo de una manera mucho más profunda y trascendente que el mero mantenimiento de unos reconocibles estilemas. La singularidad de la poética horaciana de los Argensola, la experimentación de Villegas o la ya lejana y poco atendida propuesta de Espinosa en sus Flores, apenas son indicios de unas opciones poco frecuentadas. Su compartida combinación de soslayo de la expresión amorosa y recuperación de temas y motivos de la tradición grecolatina, junto a diversas formas de experimentación formal (menos marcada en los hermanos aragoneses) se presentan a partir de la muerte de Bartolomé Leonardo como muestras de caminos que pudieron ser transitados y quedaron en excepciones a una regla general ${ }^{4}$.

La norma la seguía marcando la persistencia en el tronco común de la poética establecida en la parte central y más reconocida de la lírica garcilasiana, la que aclimata al Petrarca del Canzoniere en nuestra tradición y neutraliza en ella

2. Elias L. Rivers, «El problema de los géneros neoclásicos y la poesía de Garcilaso», en Academia Literaria Renacentista. IV. Garcilaso, ed. Víctor García de la Concha, Universidad de Salamanca, 1986, pp. 49-60. Véase también Rafael Lapesa, La trayectoria poética de Garcilaso (Madrid, Alianza, 1984), en Garcilaso: estudios completos, Madrid, Istmo, 1985.

3. Para lo relacionado con el sistema genérico en la lírica áurea son de referencia los trabajos del Grupo PASO, recogidos en La poesía del Siglo de Oro. Géneros y modelos, dir. Begoña López Bueno, Universidad de Sevilla, 2008 (CD-rom con la recopilación de los volúmenes previos); y La renovación poética del Renacimiento al Barroco, coord. B. López Bueno, Madrid, Síntesis, 2006.

4. He desarrollado estas ideas en Entre Narciso y Proteo. Lírica y escritura de Garcilaso a Góngora, Vigo, Academia del Hispanismo, 2007; «Renovación del orden genérico: las Flores de Poetas Ilustres (1605)», Calíope, 9,1 (2003), pp. 5-33; y, más específicamente, en «La epístola entre dos modelos poéticos», La Epistola (dir. B. López Bueno), Universidad de Sevilla, 2000, pp. 311-372. 
todas las formas previas de sentimentalidad, filografía y retórica (cancionero cortés, dolce stil nuovo, Ausias March...). Como resultado, se impone una poética indisolublemente ligada al amor como experiencia trascendental, espacio para la exploración de los sentimientos de un individuo incipiente, tendencia al sufrimiento y decantación por un lenguaje que tiene como premisa la transparencia y la expresividad. Las variantes del altobarroco, en lo que se refiere a la línea dominante, representada por Lope y Quevedo, profundizan en este discurso compartido, sin que las muestras de cambio (en las que se perciben las diferencias epocales) alteren en lo sustancial la persistencia de una poética. La ausencia de una construcción unitaria a la manera de las Rime sparse petrarquescas no impugna la continuidad de una concepción poética cuya fragmentación debe posiblemente menos a los cambios de orden epistemológico que a los derivados de las prácticas editoriales. Y ello se manifiesta de manera más intensa a partir del ecuador del siglo XVII, cuando, muertos ya los grandes referentes líricos, se inicia una deriva que, sin una solución de continuidad clara con sus raíces, apunta hacia el giro de la poesía ilustrada a través del recorrido por las formas neoclásicas, también las ligadas por antonomasia a la poética dieciochesca. Es ese desplazamiento sin ruptura el que podemos rotular como bajo barroco, sin que el concepto se superponga sobre la revisable consideración de la degeneración barroquista. Al considerar, siquiera sea de manera parcial y muy tentativa, los avatares de uno de los géneros neoclásicos destacables ya en la escritura garcilasiana más madura, podemos ensayar una vía para una lectura del período lírico comprendido entre el Parnaso español de Quevedo y la muerte de Eugenio Gerardo Lobo más productiva desde el punto de vista crítico e historiográfico que la mera negación a impulsos de una pretendida falta de calidad poética 5 .

Agotados por Lope y Quevedo los recursos de la poética de base petrarquista y malinterpretada la propuesta gongorina, la renovación de la poesía en la segunda mitad del siglo XVII y la primera mitad del siguiente pasaba por la exploración de unos registros que, en las antípodas de la poética amorosa dominante, rozaban con lo que pudiera ser considerado como una falta de lirismo, como una carencia de aliento poético que lindaba con el prosaísmo, al que se acogió una crítica perezosa como fácil argumento de desautorización. Frente a este extendido anatema, cabe explorar lo que esa deriva estilística, ligada a un replanteamiento radical del tema dominante en los versos previos, apunta en el horizonte de un proyecto de renovación poética, que había de pasar necesariamente por la superación del sujeto poético fraguado en la lírica y la ideología petrarquista. Se trataba de un sujeto caracterizado por su refugio en la interioridad y la tendencia a constituirse como un ente monolítico, más justificado por su escritura que por su propia vida. Y es que en la escritura, desde

5. Como eje del mencionado proyecto de investigación estamos desarrollando una página web, PHEBO. Poesía Hispánica en el Bajo Barroco (http://phebo.es/), con un repertorio bibliográfico y una colección de textos editados, entre otros materiales, como base para una revisión historiográfica y crítica de la lírica del período. 
su consideración, es posible reducir a la unidad (la del Canzoniere) todos los elementos de la experiencia, agavillados en un «yo» que pasa de forma gramatical a soporte y justificación del individuo ${ }^{6} \mathrm{y}$, de rebote, como base paradigmática, si no exclusiva y excluyente, de la expresión lírica. Por el contrario, la vida, sobre todo cuando no se limita a los estrictos límites de la intimidad, se abre a la variedad, no exenta de unas contradicciones que se acentúan con unos acontecimientos de los reinos hispánicos que pautan la decadencia del imperio, el desplazamiento de la centralidad en el mundo conocido (también el cultural), las sucesivas crisis en lo económico, en lo social, en lo científico y en lo ideológico y, finalmente, un cambio de dinastía reinante, termómetro antes que motor, de una transformación que acabaría de aflorar con la llegada al trono de Carlos III7. Pero eso nos llevaría más lejos de lo que aquí se trata de apuntar, al menos como hipótesis, resumida en una extensión de la pérdida de la hegemonía y de su conciencia que abarca no sólo la descomposición del imperio, sino también la revisión de la poética dominante, ambos extremos con un punto de intersección en la recomposición del sujeto y sus relaciones con su marco social, en el camino que lleva a la construcción del sujeto moderno, con su escisión entre la intimidad y la dimensión pública ${ }^{8}$.

Situándonos en una perspectiva literaria stricto sensu, la establecida por unos criterios de caracterización de los géneros poéticos de base estructuralista, encontramos en el sistema de «contragéneros» propuesto por Claudio Guillén para las modalidades forjadas en el horizonte neoclásico garcilasiano ${ }^{9}$ un punto de vista de notable fecundidad, tanto para el esclarecimiento de los rasgos históricos de una modalidad genérica como para apreciar a través de los mismos el complejo problema de las relaciones entre poesía y sociedad, eje compartido al que se ciñen estas reflexiones. En el juego de presencias y ausencias, de afirmaciones y negaciones, que Guillén establece para la ordenación de oda y elegía, epístola y sátira, en una relación de doble eje, es posible establecer una clave para preguntarnos a la vez por el lugar de la vida social en la poesía (¿qué es lo que se celebra o se niega, se ańora o se cuestiona?) y por el papel de la poesía en el seno de la vida social. Y esto, que es lo que Saussure pretendía para la semiótica como estudio de los signos y lenguajes, no es lo menos importante. Ya han sido recorridos, y hasta más allá de donde resultaba prudente hacerlo, los caminos críticos derivados de la consideración meramente mimética del

6. En la cronología que nos ocupa la lectura humanista del individuo se disolverá ante los embates del pensamiento filosófico que va desde el empirismo criticista de Bacon al idealismo de Hume, sentando las formas de un nuevo humanismo, el burgués.

7. Una importante revisión de este proceso se encuentra en Jesús Pérez Magallón, Construyendo la modernidad: la cultura española en el «tiempo de los novatores» (1675-1725), Madrid, CSIC, 2002.

8. Una reciente y esclarecedora aproximación a esta línea de fractura en el discurso a las puertas de la modernidad ilustrada es la de Juan Carlos Rodríguez, Tras la muerte del aura (En contra y a favor de la Ilustración), Universidad de Granada, 2011.

9. Claudio Guillén, «Sátira y poética en Garcilaso», El primer Siglo de Oro, Barcelona, Crítica, 1988, pp. 15-48; y «Sobre los comienzos de un género: hacia la oda en España», en La Oda, dir. Begoña López Bueno, Universidades de Sevilla y Córdoba, 1993, pp. 149-173. 
texto literario, del texto poético, indagando en su espacio el reflejo de las modas y maneras de su entorno social. Hora es de avanzar en la exploración de la relación complementaria, esto es, el modo en el que la construcción literaria se inserta en su contexto y responde al mismo. Tanto como la elucidación de los mecanismos poéticos se obtendrá en esta vía una comprensión más cabal del funcionamiento de la trama de la sociedad, comenzando por el lugar que le reserva a la poesía como forma de belleza, de expresión individual y, en particular, de manifestación de las relaciones interpersonales y grupales. Por ello, resultarán especialmente apropiados para esta indagación aquellos géneros que, como los neoclásicos, desbordan los límites de la subjetividad individual para establecer una referencialidad y una pragmática distintas a la pura expresividad de los sentimientos, para apuntar a un diálogo en torno a la realidad objetiva (entiéndase, compartida en el espacio del mundo social), con una clara manifestación en el escenario de la comunicación epistolar. De ahí su interés para el propósito que nos ocupa y, al tiempo, para la adecuada perspectiva crítica sobre el cambio poético operado a partir del ecuador del siglo XVII.

\section{SíNTOMAS DE UN CAMBIO}

No son pocos los que se van consolidando a partir de la edición póstuma de Quevedo. Por más que la fórmula consagrada por González de Salas persistiera, y en casos tan relevantes como los de Solís (1692) y Salazar y Torres (1681), y aún Álvarez de Toledo en pleno siglo XVIII, lo que muestra un análisis de la producción editorial del período en el campo de la lírica es la creciente regularización del modelo de «libro de poesía» ${ }^{10}$ realizado en vida del autor, razón por la cual en la mayoría de las ocasiones no tiene un carácter completivo, sino que se plantea y se presenta abierto a la posibilidad de nuevas entregas autoriales y editoriales ${ }^{11}$. Causa y consecuencia, el volumen de poesías líricas así configurado se vincula a un cambio en la caracterización del público y de los creadores, en torno a los apuntes de unas tendencias de consumo cultural y la incipiente industria editorial que puede satisfacerla. El avance hacia la figura del lector moderno (comprador de libros impresos y consumidor de los mismos en la intimidad de su gabinete, en una lectura silenciosa e individual) es paralelo a la consolidación del autor en su camino a la profesionalización, con todos los factores vinculados a lo que apunta a un modus vivendi: comercio regular con la imprenta, lenguaje y temas ajustados a los mecanismos de

10. Puede consultarse ahora a este respecto El libro de poesía (1650-1750): del texto al lector (coord. Pedro Ruiz Pérez), monográfico del Bulletin Hispanique, 113, 1, 2011.

11. Así ocurre, por citar a los autores en que nos detendremos, del volumen póstumo de Solís a las diferentes entregas de Benegasi, y, en este caso, de la obra lírica del padre a la del hijo, en una cronología dieciochesca en la que Villarroel se presenta como referente de las dos prácticas editoriales y no sólo en el caso de la lírica. 
recepción, conciencia de la objetivación (cuando no alienación) de su trabajo y redefinición, en síntesis, de su papel en la sociedad ${ }^{12}$.

Un dato perfectamente ilustrativo de esta situación es el número de poemas contabilizados en la prensa periódica de la primera mitad del siglo XVIII, superando con mucho la cantidad de 5.000 composiciones y un número proporcional de versificadores. Las páginas de diarios y revistas, verdaderos iconos de la sociabilidad de la comunicación (y de la comunicación social), representan, más que el contrapunto, el complemento al libro de poesía como cauce privilegiado de la expresión lírica. Su soporte específico potencia dos componentes clave de la nueva escritura: su carácter fragmentario y su apego a la circunstancia. Las entregas periódicas no son el escenario más apropiado para la construcción de una subjetividad trabada como base de la identidad (social y poética) a partir de la construcción de un discurso unitario y cerrado. Tampoco puede percibir tal identidad el lector que se acerca a unos versos emparedados, en su lectura y en el propio espacio de la página, entre la noticia tremendista, la crónica política o el anuncio comercial de un específico. Son textos sin continuidad necesaria, manifestación de una práctica autorial oscilante entre la voluntad de intervención en la sociedad y la mera obtención de un sustento económico. El éxito se vinculará a la popularidad de una firma, una rúbrica que, como muy bien supo entender y explotar Torres Villarroel, se convierte en una marca comercial, nunca en una revelación de la interioridad del autor, ni siquiera de su verdadero rostro humano ${ }^{13}$.

Así, mientras el verso se circunscribe al espacio impreso, en formato libro, en los sostenidos pliegos o en las páginas de los diarios, el horizonte de la poesía se amplía, dando cabida a parcelas de la realidad y a temas que no tenían entrada en la lírica sentimental. Aparece la dimensión de lo público como contrafaz de la dimensión privada, y, mientras dicha dimensión se expande, también lo hace el público de la poesía escrita, un público que en su heterogeneidad no ocultaba una dimensión compartida, aquella por la que se apartaba de la recepción colectiva de una poesía oral u oralizada, ya fuese la de la recitación del ciego o la de la engolada representación de un certamen académico. La modificación de las relaciones entre autor y lector, cada vez más comercializadas en el orden externo, se traduce en una inevitable alteración en los modelos pragmáticos habituales en la poesía barroca, tanto en el orden extradiegético como en lo propio del plano intradiegético, el de la relación entre la voz poética y su destinatario inmediato, su confidente, su discípulo o su corresponsal.

12. Un amplio panorama de esta compleja realidad lo ofrece ahora El autor en el Siglo de Oro. Su estatus intelectual y social, ed. Manfred Tietz y Marcella Trambaioli, Vigo, Academia del Hispanismo, 2011. De manera más específica, véase Pedro Ruiz Pérez, La rúbrica del poeta. La expresión de la autoconciencia poética de Boscán a Góngora, Universidad de Valladolid, 2009.

13. Para el caso de una de las más complejas figuras autoriales del período, incluyendo su faceta poética, es iluminador el estudio de Fernando Durán López, «A vueltas con la Vida de Torres Villarroel: ¿Relato picaresco o autobiografía moderna?», Edad de Oro, XXXI, 2012, pp. 149-180. 
Son los tiempos de la institucionalización de la literatura, como práctica y como noción, cuando se pasa del parnaso a la república literaria, a las puertas de un verdadero campo literario ${ }^{14}$. Aunque aún algo lejano, se intuye ya el horizonte del proceso de institucionalización complementario (y necesario) al de la literatura: el de la nación, cuyos rasgos empiezan a aflorar por entre las grietas de un trono en decadencia ${ }^{15}$. La política comienza a desplazarse hacia la plaza pública, con la aparición de una nueva clase gobernante, la de los letrados, que con su formación desplazan a la nobleza de la sangre en su patrimonial papel de rectores en el entorno de la corte. Un vínculo estrecho se aprecia entre este cambio en las formas de la política, la atención en la formación letrada a la retórica y a la suasoria y el auge de la conversación como manifestación propia de los nuevos espacios de sociabilidad ligados a la formación de una burguesía incipiente que busca en sus salones una alternativa a las galerías y despachos de palacio ${ }^{16}$. Si en los albores del siglo XVIII el nuevo escenario da lugar a nuevas formas de comportamiento, incluidos los usos amorosos ${ }^{17}$, no es de extrañar que propicie también el desarrollo de prácticas y retóricas poéticas antes, si no desconocidas, muy poco atendidas o desdeñadas. Lo conversacional se convierte no sólo en signo de distinción (hasta el extremo de la majeza); es también uno de los signos de los tiempos, en un avance apreciable ya en las décadas finales del siglo XVII.

La tendencia a imprimir de los poetas y las demandas de lectura incluyen, en el marco de los cambios de sociabilidad y definición de los individuos, la celebración pública y los asuntos privados, con una tendencia progresiva al despojamiento de la trascendencia: la ocasión para el despliegue festivo, con su amplificación retórica, deja paso al relato de la anécdota, del hecho trivial, cotidiano; la experiencia de lo sublime, en el amor humano o el divino, se reubica entre la diversidad de registros de una agenda humana cada vez más volcada en formas de relación interpersonal donde el sentimiento es desplazado por la utilidad, por la convención. Entre buenas maneras llenas de artificio, la

14. El monográfico La Formation du Parnasse Espagnol XVe-XVIII Siècle (coord. Pedro Ruiz Pérez), Bulletin Hispanique, 109, 2, 2007 continuó el dinamizador y fecundo proyecto, plasmado en anteriores coloquios y monográficos del Bulletin Hispanique, dirigido por el recordado François Lopez. A lo largo de varios años se sentaron unas bases sólidas para el estudio de esta realidad en el caso español. Trabajos más específicos en el ámbito de la poesía se recogen en El Parnaso versificado. La construcción de la república de los poetas en los Siglos de Oro, coord. P. Ruiz Pérez, Madrid, Abada, 2010.

15. Véase Literatura y nación. La emergencia de las literaturas nacionales, ed. Leonardo Romero Tobar, Prensas Universitarias de Zaragoza, 2008; y, para el período que estudiamos, Joaquín Álvarez Barrientos, "Nación e historia literaria a mediados del siglo XVIII en España», en Historia literaria / Historia de la literatura, ed. Leonardo Romero Tobar, Prensas Universitarias de Zaragoza, 2004, pp. 101-114.

16. El desarrollo y, sobre todo, las consecuencias de este proceso se estudian en La luz de la razón. Literatura y cultura del siglo XVIII. A la memoria de Ernest Llluch, ed. Aurora Egido y José Enrique Laplana, Zaragoza, Institución «Fernando el Católico», 2010.

17. Véase Carmen Martín Gaite, Usos amorosos del dieciocho en España, Madrid, Siglo XXI, 1972. 
metáfora se difumina, porque no hay una realidad otra a la que remitir: lo que importa, lo único real, es lo inmediato, ceñido a unas pautas sociales donde la distancia no es la impuesta por la concepción alegórica propia del alto barroco ${ }^{18}$, sino la máscara de un sujeto que rehúye manifestarse en lo más íntimo, en lo más trascendente, y busca las formas de la ironía. Satírica o intrascendente, la burla y sus mecanismos bajobarrocos pueden seguir alimentándose del concepto forjado en la época precedente ${ }^{19}$. La diferencia es que su uso ya no persigue restablecer el orden oculto tras las apariencias; lo que asoma es un relativismo ligado de forma más o menos consciente al escepticismo surgido de la crisis de la conciencia epistemológica ${ }^{20}$ y desembocante en esa forma de tibio cinismo que se consideraba marca de buen tono en las convencionales normas que regían la práctica social de los salones.

Más que una oposición abierta, se abre una productiva dialéctica entre los dos polos, vinculando los modelos del pasado inmediato y las condiciones del presente. De una parte, la del alto barroco, operan las formas de la «poesía pública»; son las prácticas y registros propios de una vida social marcada por lo celebrativo, la de los certámenes y academias, pero también la de las tertulias y salones que se extienden durante el período Borbón, como resultado del desbordamiento de las formas aristocráticas más allá de su marco natural, el del ámbito cortesano, para deslumbrar al pueblo o para suscitar la imitación por la ascendente burguesía ciudadana. De otra parte, la del bajo barroco, se consagra una "poesía publicada», que da forma a un nuevo modelo de sociabilidad donde lo público se perfila como el territorio dominante ${ }^{21}$, sofocando los elementos de intimidad, al menos tal como ésta se configuraba bajo el paraguas de la sentimentalidad comenzada a forjar en el humanismo renacentista y manifestada de manera privilegiada por la lírica de base petrarquista.

Los registros poéticos del período, entre la entropía del discurso barroco en su forma plena y el establecimiento de la mentalidad ilustrada, aparecen inequívocamente unidos a estas transformaciones, dando cuenta en su forma (y no sólo en sus temas) de una nueva actitud, un gesto social que trasciende el estricto ejercicio de la escritura y sus rasgos característicos. Es un giro que, en nuestro campo, sólo puede operarse a partir de los materiales heredados, sin corte brusco con los mismos, pero sometiéndolos a una reelaboración, resultante en una economía diferente para su uso y caracterización. Y el proceso se apoya de

18. Es de obligada referencia el estudio clásico de Walter Benjamin, El origen del drama barroco alemán, Madrid, Taurus, 1990. Sigo sus planteamientos en El espacio de la escritura. En torno a una poética del espacio del texto barroco, Berna, Peter Lang, 1996.

19. Su valor queda asentado en las monografías de Antonio Pérez Lasheras, «Fustigat mores»: hacia el concepto de la sátira en el siglo XVII, Universidad de Zaragoza, 1994; y Más a lo moderno (Sátira, burla y poesía en la época de Góngora), Zaragoza, Tropelías, 1995.

20. La analizó Paul Hazard, La crisis de la conciencia europea (1680-1715), Madrid, Alianza, 1988.

21. Véase lo señalado al respecto por Juan Carlos Rodríguez en, entre otros estudios sobre el tema, Moratín y el arte nuevo de hacer teatro, Granada, Caja General de Ahorros de Granada, 1991. 
manera sustancial en el mecanismo de elección, en el reequilibrio en el esquema de las formas y géneros, reflejando en la emergencia y preponderancia de algunos de ellos una actitud que ya no es la sostenida por los autores de la primera mitad del XVII. La revitalización del romance, en el plano del metro, es una de esas manifestaciones ${ }^{22}$. La actualización de lo epistolar, también en poesía, constituye una nueva evidencia. La fusión de ambos resultaba casi inevitable, y durante unas décadas adquiere un desarrollo inusitado y significativo el cultivo de romances epistolares o de epístolas en ese metro-género, que no siempre es lo mismo. Sí es en ambos casos una muestra privilegiada de la renovación social que se está produciendo y, cómo no, de la renovación poética que la acompaña, y en estrecha unión. Relación de acontecimientos, coloquialidad, vínculos de amistad o de salón y una cierta distancia, inherentes al texto misivo, se apuntan como elementos determinantes en la interpretación de ese doble objeto conformado por la poesía y la sociedad bajobarroca.

\section{MODELOS DE POESÍA «SOCIABLE»: UNA HUELLA Y UN PROBLEMA CRÍTICO}

Cuando el poeta a mediados del siglo XVII busca una salida a la clausurada expresión de la sentimentalidad halla una vía inmediata en las formas de la poesía pública. En ella el modelo más actuante es el proporcionado por los abundantes marcos celebrativos y por las convocatorias de certámenes y academias a las más diversas ocasiones ${ }^{23}$. Arropadas por la teatralidad característica del alto barroco, estas composiciones gozan de una amplia aceptación entre todo tipo de receptores, incluidos los posibles compradores de libros. Como contrapartida, los autores que pretendían dar sus versos a la imprenta se encontraban con la dificultad de la transposición de esas composiciones públicas a las páginas de un volumen, para que funcionen en su lectura como un poema exento. El problema no era menor, ya que se trataba de compaginar dos modalidades de lectoescritura específicas y con rasgos contrapuestos. La pérdida de la referencia inmediata deja en el aire una retórica de la presencia, propia del género epidíctico y extendida a una gran parte de la poesía pública. Diluida la inmediatez pragmática en una distancia temporal, espacial y de contexto, la misma tonalidad exaltada y oratoria, propia de la puesta en escena de la declamación, también pierde casi todo su sentido para los lectores, que buscan algo distinto en las páginas. La abundante rotulación alusiva a las circunstancia

22. Sobre ello llamó la atención, en estudio seminal, Antonio Alatorre, «Avatares barrocos del romance (de Góngora a sor Juana Inés de la Cruz)», Nueva Revista de Filología Hispánica, XXVI (1977), pp. 341-459; recogido más tarde en Cuatro ensayos sobre arte poética, México, El Colegio de México, 2007, pp. 11-191. He aplicado otro planteamiento a casos concretos en «Para una caracterización del romance en la segunda mitad del siglo XVII», en Edad de Oro, XXXII, en prensa.

23. Puede hallarse un buen muestrario de las huellas impresas de esta actividad en Alain Bègue, Las academias en la segunda mitad del siglo XVII. Catálogo descriptivo de los impresos de la Biblioteca Nacional de España, Madrid, Biblioteca Nacional, 2007. 
de origen caracteriza los libros de estos años, a modo de recurso que trata de paliar el vacío de esta traslación. Prolifera así el sintagma «en ocasión de», a modo de información para el lector, pero la recurrencia es claro indicio de la conciencia de lo diferido que comparten el poeta y sus lectores.

El libro impreso abre un nuevo espacio frente a la plaza pública, el espacio neutro y vacío que se llena al compás de cada lectura, de cada actualización, cada vez más remota de la circunstancia original. El gusto por el panegírico o por el conocimiento de eventos recreados en las relaciones, por otra parte, se convierte en una demanda activa de este tipo de poesía por parte del público lector, y en ello coincide con la voluntad de permanencia que el poeta busca para sus versos una vez apagado el motivo que les dio origen. Nueva forma de teatralidad, aunque menos espectacular, el libro que recoge estas composiciones ha de componer para el lector una especie de «ilusión escénica» ${ }^{24}$, en la que la huella escrita permita revivir el marco de la circunstancia, superando la distancia. La distancia, sin embargo, existe, y lo evocado ofrece una lejanía que convierte lo celebrado en una ausencia, apenas salvada por la palabra rimada. De la manera más rotunda y directa los versos nacidos al hilo de la circunstancia materializan la empresa esencial de la poesía de sobreponerse a la muerte, de vencer el olvido. $Y$ en este marco general para una parte sustancial de la poesía impresa se extiende con carta de privilegio ese género que de manera específica, según la citada formulación de Claudio Guillén, se erige para negar la ausencia. La epístola poética encuentra así una forma de revitalización tras los avatares del género en el humanismo y el alto barroco, desde la modalidad horaciana a la moral.

Un nuevo factor se suma conforme el XVII llega a su fin y el nuevo siglo se abre con un cambio de dinastía y en las costumbres mundanas. Una nueva sociabilidad ocupa el tiempo y las actitudes de hombres y mujeres, habituados a las conversaciones de los salones y las noticias de los diarios, educados en nuevas formas de galantería y una visión y vivencia renovadas de la vida ciudadana. Misivas y billetes se cruzan en las reuniones sociales, mientras crónicas y noticias informan de lo sucedido al otro lado de la ciudad o a centenares de kilómetros, en tanto hombres y mujeres conversan y debaten extendiendo una forma de llaneza. En tal contexto, pocas modalidades de la comunicación, incluida la poética, ofrecen un espacio más acomodado que el de la epístola, con su soltura de tono y de estilo, alejada de la afectación y abierta a dar cabida a los materiales más dispares, incluidos aquellos que se hallaban a medio camino de la solemnidad de la celebración y la trivialidad de muchas convocatorias académicas. A caballo entre ambas, el poeta encontraba ancho camino para sus rimas, y los lectores, una cauce inmejorable para sus demandas y expectativas.

La epístola poética, o quizá sería mejor decir la poesía epistolar, acompaña así una profunda redefinición del espacio de lo interpersonal en el marco de lo público, de lo social. Y lo hace de una manera muy variada, hasta hacerse casi difusa. Por un lado, se aprecia una cierta disolución de la referencia genérica

24. Véase el citado estudio de Juan Carlos Rodríguez sobre el teatro moratiniano. 
en el título o en los epígrafes de los poemas. Del lado opuesto, asistimos a una revitalización de lo epistolar en verso, con una amplia gama de poemas que acogen y desarrollan las marcas retóricas y pragmáticas de la epistolaridad, de la comunicación entre corresponsales unidos por un vínculo que ya no es el del amor que ataba al hablante lírico en el núcleo de la poesía anterior. Los destinatarios ahora se multiplican, al par que se intensifica la vida social y las relaciones de los individuos con que se identifica el poeta. Sigue presente el Fabio heredado de la poesía consagrada por Fernández de Andrada, mientras a su lado se dibujan los perfiles más o menos borrosos de un amigo, un familiar, un corresponsal o, sencillamente, un conocido. Con ellos gana terreno la relación de cercanía y, sobre todo, una creciente concreción, con un destinatario real que convierte el poema en el correlato metrificado de una efectiva comunicación epistolar, en la que se traban las relaciones de la amistad, en bastantes casos sobre materia literaria. Las cartas en verso ofrecen de este modo una vía para la resolución de un problema esencial: ¿Qué espacio queda para lo interpersonal cuando han perdido vigencia los pretéritos ideales del caballero, del cortesano y del humanista? ¿Cuál en el margen que queda para la expresión poética cuando se busca sustituir la melancolía introspectiva, propia de la tonalidad elegiaca de la poesía culminada por el petrarquismo, por la proyección de una poesía social en sentido amplio, esto es, publicada y útil, siquiera sea para rellenar los espacios de ocio de una sociabilidad mundana?

No es un problema menor para los poetas del momento, que han de enfrentarse a la empresa de reelaboración de un modelo clásico y marcado por el aura de prestigio y dignidad de una veta que pasa por Horacio y la epístola moral de la primera parte del siglo XVII. Sobre la revisión del género y su actualización se suma una dificultad añadida, la de insertar lo epistolar en el marco de un «libro de poesía», en busca aún de su definición como unidad editorial en lo que se refiere a sus mecanismos de estructuración y significación. Una de las posibles vías, y no de las menos frecuentadas, pasaba justamente por una extensión, más allá de los límites del género en sentido estricto, de la epistolaridad como tono y marca, que puede atravesar de manera sutil un amplio conjunto de poemas de los recogidos en un volumen. Así deja en ellos distintos rasgos de identificación (destinatario, materia, tonalidad...), hasta convertir este registro difuso, teñido por una llaneza conversacional en el tratamiento de temas cercanos a la cotidianidad, en seña de identidad de esta poesía. En gran medida hubo de sufrir por ello una mantenida tacha de prosaísmo, sin vislumbrar esta crítica lo que manifiesta de un intento de recomponer, a partir de la actualización de un género (neo)clásico, las precarias relaciones entre la poesía y la sociedad que se iniciaba con el período de los novatores.

\section{Dos calas: Antonio de Solís y José Joaquín de Benegasi}

A falta de completar un estudio sistemático del desarrollo de la epistolaridad en la composición de los volúmenes de poesía impresos entre 1650 y 1750, podemos detenernos en una primera aproximación a dos casos que bien 
pudieran tomarse como representativos, por las diferencias en el perfil autorial y relación con la imprenta, la compartida aceptación de los lectores y las fechas en que se sitúa la producción y edición de sus obras; en la poesía de ambos se encuentra lo epistolar, bien que en distinto modo, con unos matices susceptibles de iluminarse a la luz de las diferencias anteriormente apuntadas.

Con las Varias poesías sagradas y profanas (Madrid, 1692) de Antonio de Solís nos encontramos ante un volumen póstumo, cuya edición corrió a cargo de Juan de Goyeneche, con un particular cuidado en desplegar todas las estrategias de canonización en el campo de la lírica adecuadas a un autor que, como cronista, ya gozaba de consideración y respeto ${ }^{25}$. Las sucesivas reediciones en 1716 y 1732 vendrían a mostrar que la decisión editorial no andaba errada, y que la conexión con el gusto lector se mantuvo durante varias décadas, hasta cerca del límite establecido para nuestra investigación. En lo tocante a la escritura, habría que adelantar considerablemente la fecha de composición de los poemas, en todo caso, antes de 1686, cuando fallece el escritor. Aun sin tomar ad pedem litterae el socorrido tópico de la datación juvenil de las composiciones líricas, siguiendo el modelo de la tradición virgiliana, hay que considerar la insistencia del editor al recordar el giro en la trayectoria autorial de Solís, no sólo por su profesión religiosa, sino también por su dedicación profesional a la escritura de la historia como cronista real. De hecho fue la Historia de la conquista de México (Madrid, 1684) la que determinó su reconocimiento (más que el volumen que daba cuenta de su labor de dramaturgo, Comedias, Madrid, 1681) y le avaló para convertirse en referencia en la calidad de la prosa, hasta ocupar un lugar de relevancia entre las "Autoridades» del Diccionario académico. La "Vida» del «Oficial de la Secretaría de Estado, Secretario de su Majestad y su Cronista Mayor de las Indias» con que Goyeneche abre y canoniza su edición ${ }^{26}$ presenta al lector un talento precoz: su escritura pública es ya patente durante sus estudios universitarios en Salamanca, con apenas 17 años; tras sus estudios, la acogida en la corte y una relación de mecenazgo propiciaron el lucimiento de su ingenio, hasta que Felipe IV le otorga los cargos oficiales que lo vinculan a la administración, donde los juguetes líricos irían cediendo su lugar a una escritura más en seso. Con estas razones, en tanto no se complete un análisis más pormenorizado para la datación de cada uno de los poemas, podemos acercar bastante al ecuador de la centuria los versos líricos de Solís, en especial los que están más lejos de la escritura en seso.

25. Trato este aspecto en «Edición y canon: la publicación póstuma de Antonio de Solís (1692)", en Jornadas de Estudios Románicos. Sección de Hispanística. Tomo I: Literatura, ed. Bohdan Ulasin y Silvia Vertanová, Bratislava, AnaPress, 2009, pp. 257-269.

26. Puede compararse a la operación de Vera Tasis en la edición de la Cítara de Apolo, que estudio en «Salazar y Torres: autoridad y autoría de una obra póstuma», en El autor en el Siglo de Oro, ed. cit., pp. 361-377. 
Al recoger esa producción más o menos juvenil, plasmada en 190 composiciones, Goyeneche no introdujo variaciones en la práctica editorial más frecuente ${ }^{27}$ $y$ las ofrece ordenadas por metros; el resultado es el siguiente ${ }^{28}$ :

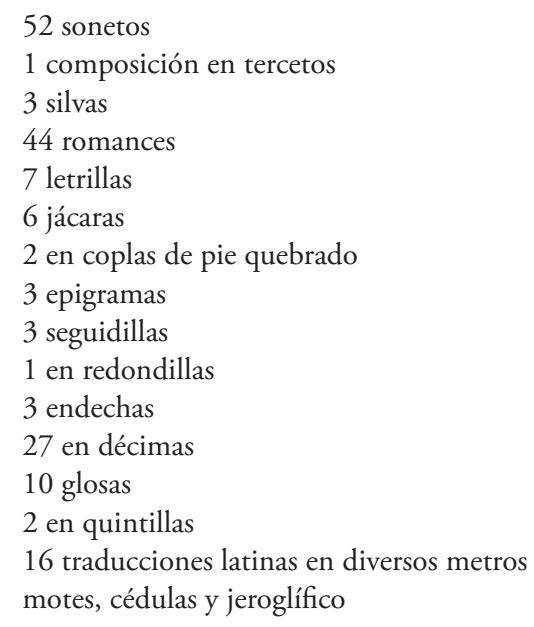

Si atendemos a la presencia de lo epistolar, como denota la escasez de composiciones en tercetos, encontramos que las muestras se encuentran bastante restringidas, en cantidad y en diversidad cualitativa, ya que tampoco es muy abundante la variedad en la casuística de situaciones comunicativas. Como composiciones epistolares podemos considerar con claridad cinco piezas:

1. Al marqués de Salinas, en ocasión de su casamiento y en respuesta a una carta suya. Romance

2. Responde a un amigo (Fabio). Romance

3. [A una dama que no respondía muchas cartas de su amante. Romance]

4. Respuesta a una consolatoria. Romance

5. Envío de unas almendras. Romance

Con un criterio de relativa amplitud, podría sumarse a este selecto corpus la [Elegía consolatoria a doña Inés de Rojas. Tercetos]. Pero donde la propuesta genérico-pragmática se enriquece es en el apartado de las piezas breves, donde registramos hasta 11 composiciones en décimas que muy bien pueden leerse como verdaderos billetes de envío, breves notas con que el poeta acompañaba la remisión de algún objeto, y que remiten ellas mismas a lo más propio de la correspondencia, como intercambio de palabras, noticias y objetos. Estas piezas nos sitúan de lleno en uno de los puntos de más consideración en el estudio de las relaciones entre el verso y la vida cotidiana. Pero vayamos por partes.

27. Desde la compilación de obras gongorinas en el manuscrito Chacón a las ediciones de Benegasi el predominio del criterio métrico para la organización del volumen de poesía se extiende de manera apreciable, como muestran las ediciones de Esquilache (1663), Delitala y Castelví (1672), Nunes da Silva (1671) o Salazar y Torres (1681).

28. Sigo la «Tabla segunda, de los asuntos», incluida al final de la edición. 
El lector no encuentra en ningún caso impreso el rótulo de «epístola». La omisión es tan atribuible al escritor como al editor; o, dicho en otra forma, la caracterización genérica del membrete no se consideraba operante en la cronología de la escritura ni en la de la lectura, si no es que en ambas se intentaba rehuir una designación que remitía con excesiva claridad a un modelo clásico y, muy posiblemente, a la variante moral del altobarroco. No eran estas, en ningún caso, las marcas que Solís pretendía concitar para sus versos, como denotan los temas apuntados en los epígrafes de los poemas.

Muy en relación con el tono menor correspondiente a una temática cercana a lo cotidiano se impone el abandono prácticamente total (salvo en la modalidad elegiaca) de los canónicos tercetos, vinculados desde su inicio a la epístola horaciana de manera casi exclusiva ${ }^{29}$. En su lugar se regulariza el uso del verso de romance, orientando el viejo género narrativo hacia esa otra forma de relación que se despliega en las cartas, eso sí, desprovistas ya del tono de lirismo sentimental con que el metro adquiere características genéricas en su formulación en el romancero nuevo o artístico. Ya empezaban a alejarse las pautas de sentimentalidad y expresividad poética que en el cambio de siglo dieron forma a uno de los rasgos de la estética altobarroca. Aunque el metro tiene un amplio desarrollo ${ }^{30}$, la dispersión de sus registros y la falta de un elemento unificador apartan esta producción de la noción de "romancero" aplicable a la obra de los poetas de generaciones previas. El romance aparece, pues, a modo de un cauce, si no neutro, limitado en sus rasgos de valor lírico, marcado por su cercanía a la oralidad y por su vinculación a un registro propio de lo cotidiano y lo conversacional, elementos propios de la epístola familiar y de la carta real.

Los elementos de la retórica epistolar (salutatio, narratio, petitio, despedida y data) se distribuyen de manera asistemática, apareciendo en las distintas composiciones al gusto del autor, sin acabar de configurar una carta tout court. Lo que sí se impone con carácter general es el tono jocoso, con aire de desenfado cuando no abiertamente festivo, despojando al molde epistolar del carácter moral propio del horacianismo y de una parte importante del género altobarroco. Todas aparecen "en ocasión», como en muchos de los casos de las composiciones públicas, pero en este caso bajo el denominador común de la cotidianidad, quedando sólo el epitalamio como muestra de una circunstancia destacada. El resto lo componen el acompańamiento de un regalo más bien trivial, una carta mensajera o noticiosa y dos intervenciones en la que lo amoroso se disuelve en un esquema triangular, sea por ser enderezada a una amiga de la dama, sea porque, a la manera de la ode garcilasiana, el hablante lírico intercede ante la dama de un amigo. Lo epistolar se convierte de

29. Verdadera excepción, al menos en los inicios del género, es el experimento garcilasiano con los sciolti.

30. La proporción es extensible a otros casos. Tras el soneto, es el metro de mayor cultivo y el más abierto a la experimentación formal (como señaló Alatorre, ob. cit.) y genérica (Ruiz Pérez, «Para la caracterización...», ed. cit.). 
este modo en una amplia senda para encauzar una serie de temas mundanos, cercanos a la cotidianidad, sin interferencia de la sentimentalidad y expresados en un tono conversacional.

Esa coloquialidad escrita, de una comunicación en ausencia, trenza entre el verso y la epistolaridad una red de relaciones que presentan los mismos rasgos de mundano desenfado, sin la atadura de los vínculos amorosos o las exigencias del magisterio o la moralidad. Diluida la presencia de la amada y del paradigmático $\mathrm{Fabio}^{31}$, asistimos a un intenso proceso de caracterización de los destinatarios, todos con un perfil específico, aunque sin llegar en la mayor parte de los casos a una individualización, sólo presente en los casos en que lo epistolar deriva a otras formas genéricas o se contamina de sus rasgos, como son los casos respectivos de la elegía consolatoria y el atenuado epitalamio. Un marqués, unas damas, unos amigos conforman una imagen de la sociedad mundana, tan alejada del ambiente cortesano como de la soledad del gabinete del poeta. Sin nacer en los salones, los versos reproducen su ambiente, el que se aproxima a las tertulias y las nuevas formas de sociabilidad, regidas por pautas de urbanidad y las modas al uso, aun cuando en ellas no se han impuesto aún los usos y modos dieciochescos, pero apuntando hacia ellos.

El intercambio de regalos, los cumplimientos y los juegos del galanteo pautan esa forma de sociabilidad anudada por la red de respuestas del intercambio epistolar, asentando el papel de la modalidad en la consolidación de la relación entre los versos y la práctica social, extendiendo los primeros desde su funcionamiento pragmático real «en la ocasión» hasta las páginas del libro impreso, donde contribuyen a la caracterización del tono de una poesía que se va apartando paulatinamente de la formalización ligada al sentido y la práctica de la poesía en las décadas precedentes, aun sin romper con sus rasgos más externos. Y esto aún en un autor arraigado en otras parcelas de su escritura a una continuidad con lo propio de la época de los Felipes.

Mucho más alejado en cronología y modos de los años de los Austrias menores se encuentra José Joaquín Benegasi, que bien puede considerarse un representante característico de la poesía dieciochesca en la primera mitad del siglo, antes de los albores de la poética ilustrada. Más cercano a ésta en sus fechas de escritura y de edición que de la poesía de Solís, su obra también se distancia del poeta anterior por la decidida inclinación a la imprenta mostrada por quien la frecuentó en muchas de sus modalidades, sin que su intensidad decreciera en exceso cuando, al final de su vida y tras enviudar, se acerca a la religión, para profesar en la regla agustina $^{32}$. Antes de esta circunstancia, los datos entresacados de un volumen de 1754 se nos antojan reveladores de lo más sustancial de la personalidad de

31. Como veremos, el nombre puede seguir apareciendo en alguna composición, pero lo hace sin los rasgos del discípulo. En un marco de difusa amistad, podemos ver en ello poco más que un rasgo meramente formal.

32. El poeta convierte su estado en motivo de relación epistolar en una composición en ovillejos incluida en el volumen de 1743. La incluyo en mi selección de Composiciones epistolares del autor, Madrid, Clásicos Hispánicos, 2012. Recojo un repertorio de sus obras en «Para una 
Benegasi como escritor y su lugar en el campo literario del momento. Ese año da a la luz, en octavas, la Fama póstuma del Rmo. P. Fr. Juan de la Concepción, impresa en Madrid, en la imprenta del Mercurio. Con la alabanza póstuma del fraile trinitario, con el que cruza diversos poemas de corte más o menos epistolar y recogidos en sus tomos líricos, Benegasi edita el poema heroico Escuela de Urania, del amigo muerto, "con un índice de varias obras suyas, impresas y manuscritas». Alabanza, edición y bibliografía son tres componentes básicos en el proceso de consagración de un autor. La institucionalización se completa con la incorporación de otras voces a la alabanza póstuma, y en el coro se destacan las de los presbíteros José Villarroel y Diego de Torres Villarroel, complementando un entramado de relaciones literarias, en las que ocupa un papel relevante el celebrado autor de pronósticos, figura central en el panorama literario del momento, al menos en su vertiente más mundana.

Pero Benegasi no se limita a celebrar al amigo. En el campo literario abierto en torno suyo él encuentra ocasión para situarse, y lo hace ofreciendo una relación de sus obras, que en su contenido y actitud, son la muestra más acabada del perfil literario de este autor hoy poco recordado. Dice en la nota final del volumen:

Por haberme hecho algunos autor de cierto papel que aún no he visto, prevengo no daré jamás obra mía al público que no sea con mi nombre, y son las que hasta hoy tengo dadas a luz las siguientes:

Un tomo de Poesías líricas (al que se aumentó una Carta que en estilo festivo escribí al Rmo. Concepción dándole noticia de cierto chasco que me sucedió en Loja).

Otro también Métrico, en que se incluyen algunas obras de mi padre.

La Vida de San Benito de Palermo, escrita en seguidillas, con los argumentos en octavas. En $4^{\circ}$ los 3 tomos.

La comedia burlesca cuya portada dice Comedia que no lo es, intitulada Llámenla como quisieren, su autor ella lo dirá.

Otra carta en prosa y verso noticiando cierto sueño jocoso; supuse haberla escrito don Juan Antonio Azpitarte, porque se llamaba así el criado que entonces me servía de amanuense y estaba toda de su letra.

Otro romance burlesco con el motivo del cometa último que se dejó ver en esta corte. Lo publiqué con el nombre de Juan del Rosal.

Estos libros y papeles se venden en la librería del Mercurio.

El papel de No se opone a muchos y Residencia de ingenios, en prosa y verso, se hallará en casa de don Francisco Romero, frente de la del Excmo. Sr. conde de Ońate.

La Vida de San Dámaso, escrita en redondillas, con otras poesías líricas, y entre ellas la Descripción de la ciudad de Loja. Es libro en cuarto; se vendía en la misma parte, pero ya se acabó la impresión.

La Carta escrita a cierta Señora Excma, en prosa y verso, noticiándola varios sucesos políticos \&c. se hallará donde este libro.

bibliografía de José Joaquín Benegasi y Luján. Hacia su consideración crítica», Voz y letra, XXIII/1 (2012), pp. 147-169. 
Advirtiendo que, observando lo mismo que mi amigo el Rmo. fray Juan, en ninguno de estos papeles he puesto apellido que no sea de mi casa ${ }^{33}$.

Junto a las llamativas alusiones a las composiciones epistolares, destaca la preocupación por dejar nombre, con la ambigüedad sobre el uso de seudónimos, todos ellos esclarecidos por esta declaración de autoría y la ostentosa enumeración de sus obras, sin que falte el inequívoco matiz comercial de las indicaciones de venta, incluido el agotamiento de una tirada.

En estrecha correspondencia con esta actitud, nuestro autor ofrece en el espacio de pocos años hasta cuatro volúmenes de versos, contando entre ellos el que comparte con la poesía de su padre, el dramaturgo Francisco de Benegasi y Luján ${ }^{34}$. En 1743 aparecen Poesias líricas y joco-serias (Madrid, por Joseph González); sólo tres años después hace imprimir Obras líricas jocoserias que dejó escritas el señor don Francisco Benegasi y Luján (...). Van añadidas algunas poesías de su hijo, don José Benegasi y Luján posteriores a su primer tomo lírico (...) (Madrid, en la oficina de Joan de San Martín y a su costa); generalmente se data en 1760 Obras métricas que a distintos asuntos, asi serios como festivos (aumentadas en más de la mitad en esta segunda impresión) escribia frey don José Joaquin Benegasi y Luján, canónigo seglar de nuestro padre San Agustín (...) (Madrid, en la imprenta de Miguel Escribano, s.a.), pero no sería ésta la referencia de la Fama póstuma, sino la del volumen de 1752 Poesías líricas, y entre éstas la Vida del glorioso san Dámaso (...) (Madrid, por Juan de Zúńiga). En resumen, en menos de dos décadas Benegasi publica cuatro volúmenes de poesía que, incluyendo las composiciones paternas y algunas reiteraciones, suman 840 páginas en $4^{\circ}$, lo que no es obra menor.

Los cuatro volúmenes presentan una misma disposición editorial, optando por la modalidad de la organización en clave métrica. Así, se disponen en orden repetido sonetos y octavas (cuando aparecen, sólo en el último título), romances, décimas, endechas, seguidillas, quintillas y otras piezas menores. La regularidad se muestra también a los registros temáticos y estilísticos, caracterizados por el extendido tono jocoserio. Esta continuidad aleja las obras de un perfil individual; más bien se trata de entregas editoriales, por razones de presencia en el mercado, de una obra sin otra solución de continuidad ni razones intrínsecas para una agrupación diferenciada. En lo que se refiere al uso de la epistolaridad tampoco cabe ver diferencias apreciables. Baste, pues, detenernos, por razón de espacio y detalle, en lo tocante al primero de los volúmenes, las Poesías líricas y jocoserias, de 1743. Como en el caso anterior, nos encontramos con una sistemática renuncia a la designación de «epístola» o "carta» en los rótulos introductorios de las composiciones, pero también con un recurrente empleo de las marcas retóricas y pragmáticas de la epistolaridad, y

33. Fama póstuma del Rmo. P. Fr. Juan de la Concepción (...) Escribiala en octavas don José Joaquin Benegasi y Luján, regidor perpetuo de la ciudad de Loja (...), Madrid, imprenta del Mercurio, 1654, pp. 65-67. Modernizo grafía y puntuación.

34. Un escueto perfil, a partir de las pocas noticias conservadas, y una recopilación de su teatro se encuentra en Eduardo Tejero Robledo, El dramaturgo Francisco de Benegasi y Luján (1659-h. 1743): biografía y reedición de su obra completa, Ávila, Institución Gran Duque de Alba, 2010. 
con mucha más intensidad que lo hiciera Solís, como si se hubiera intensificado lo significativo de esta marca en la caracterización de la poesía de Benegasi y, por extensión, del período. Sirva una relación de las piezas con estos rasgos:

1. Soneto de envío de cartapacio a su padre

2. Soneto en respuesta al envío de un pronóstico

3. Soneto noticioso a un amigo

4. Soneto a un amigo remitiendo una copla de Solís

5. Soneto devolviendo un libro a un amigo

6. Soneto de felicitación a una señora

7. Soneto a un amigo que hacía versos aconsejándole no frecuentar casas de señores

8. Romance epistolar a un religioso amigo

9. Respuesta al antecedente

10. Romance al marqués de la Olmeda pidiendo un papel

11. Romance a un amigo sobre las veleidades de cierta madama.

12. Romance epistolar a una señora

13. Romance respondiendo a la carta de un amigo

14. Romance remitiendo unas morcillas

15. Décimas enviando por granzas para unas palomas

16. Décimas remitiendo libro de la madre de Agreda

17. Ovillejo noticioso a un amigo.

18. Carta en respuesta de otra que le había escrito un amigo, noticiándole cierto desengańo de una parienta

19. Endechas a un ingenio culto opuesto al autor

20. Endechas a un amigo recordándole un encargo

21. Respuesta a las antecedentes

22. Seguidillas. Responde a la carta de una parienta y le da cuenta de su viaje

23. Respondiendo a uno que le pedía consejo

24. Chamberga dando a un amigo cuenta (y no parte) de las almorranas que padece.

Se impone a ojos vista el incremento del número de estas composiciones epistolares, sobre todo si consideramos la extensión considerablemente mayor del volumen de Solís. Junto al crecimiento aritmético es visible el incremento cualitativo, con una variedad mayor en la casuística a la que responden las composiciones. Lo mismo sucede con la variedad métrica, sin que la epistolaridad se ciña al cauce más habitual de los romances (cuando no se trata de los clásicos tercetos), destacando, junto a formas octosilábicas diferentes, el reiterado uso del soneto, que viene a ocupar a todas luces el lugar de los billetes misivos, con todas sus variedades: noticieros, de envío, de felicitación, de respuesta..., en fin, las actividades propias de la sociabilidad mundana del momento, en la que conviven pronósticos y encargos, libros y morcillas, a tono con lo jocoserio de los poemas, por no decir que el de los poemas responde al carácter de los usos sociales. En ellos se desborda lo «ocasional», para extender la retórica epistolar a una amplia variedad de situaciones, incluyendo las más escabrosas, como la de la última composición de la serie. También se intensifica esta retórica con la acumulación de sus elementos distintivos, desde el saludo a la despedida y firma. En definitiva, la cotidianidad invade lo literario, tendiendo un puente directo entre poesía y sociabilidad, pero también vemos hasta qué punto lo 
poético, lo literario, al menos en su sentido más amplio, forma parte de los usos de la sociedad.

De las 24 piezas resaltadas, 17 ofrecen un destinatario identificado de forma más o menos genérica. Entre ellos se incluyen el padre del poeta y una parienta, señoras en dos casos y amigos hasta en 11 ocasiones; junto a ellos se singularizan un marqués, también identificado como escritor, y un ingenio culto. Los perfiles remiten a un entorno cercano, marcado por relaciones de sangre o amistad en casi todos los casos, y con una acentuada presencia de las letras. Ello es más observable si atendemos también a los rasgos pragmáticos de las composiciones. La felicitación, en un caso, y el consejo, en dos, ocupan un espacio muy reducido, pese a ser dos de las formas más propias de la carta y de la epístola, en sus caracterizaciones tradicional y clásica, respectivamente. Sí tiene una cierta relevancia (una cuarta parte de las 24 piezas) el grupo de cartas noticieras, con una diversidad de materias, pero todas de trascendencia muy limitada. Los dos grupos mayores, con presencia equivalente, son las correspondientes, en primer lugar, a un carácter práctico, más ligado a la carta funcional que a la epístola poética; es el caso de los envíos, las peticiones o, sencillamente, las respuestas a anteriores misivas. La presencia en este grupo de morcillas, granzas y hasta almorranas denota mucho del carácter de estas piezas, verdaderos ejercicios de versificación ( $\mathrm{y}$, a veces, de ingenio conceptista) en torno a la materia más trivial, es más, francamente carnavalesca. Sin que suponga una contradicción, en abierta convivencia con estos motivos se encuentran los estrictamente literarios. A través de estos intercambios epistolares asistimos a un intenso trasiego de cartapacios y papeles, libros y pronósticos, de versos de Solís y de escritos de la monja de Ágreda, mientras que entre los destinatarios aparecen dramaturgos y amigos cultos en medio de un amplio conjunto de lectores que consumían a la vez noticias y versos, convirtiendo la poesía en un juego más de una vida social que afloraba con creciente presencia en salones y calles, pero también en las páginas de los libros impresos, convirtiendo en espectáculo, ante otros lectores más lejanos y difusos que los destinatarios iniciales de las piezas epistolares, estas muestras de versificación de la vida social.

\section{UN CASO REPRESENTATIVO}

A modo de ejemplo y como ilustración de la forma en que se textualizan algunos de los rasgos apuntados a manera de hipótesis para el discurso de la epistolaridad y su relación con los modelos poéticos y sociales en el bajo barroco, vale detenerse en una pieza representativa o sintomática del estadio alcanzado, hacia la finalización del primer tercio del siglo XVIII, por la deriva del fenómeno desde los comedios del siglo anterior. La composición se inserta en el primero de los volúmenes líricos de Benegasi, y la falta de una edición moderna hace recomendable una transcripción del texto, que ofrezco modernizada ${ }^{35}$ :

35. 1743 , pp. 266-274. Opto por una prudente actitud conservadora, rehusando algunas enmiendas de lo que bien pudieran tomarse por erratas o, al menos, ofrecen lecturas confusas; es el caso de los vv. 21, 91, 128 y 162. 
Respondiendo a uno que le pedía consejo para saberse gobernar.

Seguidillas

Hoy recibo tu carta, breve y discreta, que es como si dijese dos veces buena.

Consejitos me pides, y es cosa fuerte ver me pides lo mismo que darme puedes.

$\mathrm{Y}$ esto de dar consejos, según conozco,

es cosa que hacen muchos $\mathrm{y}$ aciertan pocos.

Eres de los segundos, y yo me temo ser, por obedecerte, de los primeros.

Pero, si no acertare según deseas, culparás tu precepto, no mi obediencia.

Y, pues los episodios no han de ser largos, como los pajaritos, vamos al grano.

El que siempre dos cosas guardes prevengo: la ley de Dios es una, y otra, el dinero,

porque, si tú le guardas y huyes de culpas, que le guardes con gracia no tiene duda.

Mas no seas de aquellos que, miserables, vemos que de sí mismos quieren guardarle,

que hay casas donde sirve toda moneda sólo de peso y susto, mas no les pesa.

Huye, pues te conviene, de los extremos, y tendrás conveniencias logrando medios.

La caridad te encargo, pues quien la tiene casi es como imposible que se condene.
Sé muy cortés con todos y haz el reparo de ser cosa que tienes como en la mano.

Quejanse los groseros de que no alcanzan:

¡Cómo han de alzar la cabeza, si no la bajan!

Que hables bien de cualquiera mi afecto encarga, pues quien bien habla de otros es quien bien habla.

Honrar a todos deben los caballeros

y dejarse de hazañas

de sus abuelos,

pues no hay cosa en el mundo

más fastidiosa

que fundar vanidades

de ajenas obras.

Con quien rińas no toques de calidades,

por ser indigno modo de ensangrentarse,

pues para darnos padres

todos sabemos

no hay a quien se le pida

consentimiento.

Y, como se pidiera,

ten por constante que los más de los chicos nacieran grandes.

De favores de damas nunca blasones, de los favores.

Y yo tengo creído

con fundamento que los que más publican consiguen menos.

$\mathrm{Y}$ si ven que tu pico peca de largo, te quedarás al pisto como el canario.

No uses de las risitas que llaman falsas, porque dicen a veces

lo que se calla.

Las palabras preñadas corren gran riesgo; repara que hay zahoríes de pensamientos.

$\mathrm{Y}$, en suma, por mi voto 
siempre importara

no des tan buenos ratos

o bien decir las cosas,

a los vecinos.

o bien callarlas.

Dos veces «bien» he dicho,

Porfiar con la fortuna

105 no es acción cuerda,

cuenta con esto,

no se pierda un sentido

porque lo siento.

Ser rendido a las damas

al noble toca,

mas que todas te salgan

como son todas.

En las conversaciones

procura, Fabio,

no parecer estatua

porque no hay quien acierte

cuando se empeña.

160

El que ha de ser herido

no hay que cansarse;

110 él, si no hay quien le hiera,

suele clavarse.

Si Dios cura te quiere,

no tiene duda,

aunque des en casarte,

115 que serás cura.

Yo tuve dos mujeres, y hoy es muy dable

que de los afligidos

me pase al Carmen.

120 Desprecia las gacetas,

pues las permiten

para la gentecita

cuidado, y bueno,

que son los que la pegan

al mejor tiempo.

Con exceso ninguna

casa frecuentes;

más vale que te llamen

que el que se nieguen.

Aun lo más primoroso

corre peligro

de San Felipe.

Hay quien tiene del turco

125 noticias raras

y no sabe de un parto

que hubo en su casa.

Otro desde su cuarto

gana un castillo,

130 y en su cueva se deja

perder el vino.

De modo que el cuidado

siendo continuo.

Repara en los muchachos,

que, cuando saltan,

cuanto más se retiran

sólo se ponga

cada cual en aquello

135 que más le importa.

Mira quién te acompaña;

ten muy presente

Fiado en otra palabra

no des la tuya,

que no suelen ser fincas

las más seguras.

lo de «di con quien andas,

diré quién eres».

$\mathrm{Al}$ que debas y venga cuando no hay blanca, ya que no halle dinero, que te halle en casa;

mira que es chasco grande

llegue a tu puerta

a que sólo le digan

que comes fuera,

pues temo que replique

(vaya de cuento):

140 Si haces versos, procura

decir en ellos,

pues versos que no dicen

sólo son versos.

De lo culto te aparta,

145 mira que es droga

necesiten linterna

para tus obras.

A uno, mi gran Gerardo, se la pedían;

150 no la pedirán para

«Cómo es dable que coma

fuera ni dentro?».

Evita con buen modo

lances y gritos;

mis seguidillas.

Has de hablar castellano,

como tu abuelo:

la morcilla, morcilla, 

y el cuerno, cuerno.
De amigos que te buscan sólo en la mesa teme, pues ves que mascan, que a ti te muerdan.
En fin, mira lo que haces $y$ lo que dices,
que en obras y palabras todo consiste.
$Y$ si las reflexionas antes que partas,

acertarás las obras

y las palabras.

Adiós, porque recelo

que, si prosigo,

me digas que por carta

remito libro.

Tuyo y mil veces tuyo,

fino y constante,

$y$ a tu obediencia siempre,

tu Benegasi.

El rótulo que encabeza el poema, debido sin ningún punto de duda al poeta que edita su propia obra, sintetiza las claves de la modalidad genérica y de su actualización en el caso concreto del poema, hasta asumir los rasgos característicos de una poética para un tiempo nuevo. En el sintagma se reúnen los tres elementos distintivos: el carácter de respuesta, la petición de consejo y la materia a la que éste se refiere. Entre la forma y la temática, la pragmática determina la especificidad de la solución bajobarroca y su distinción del modelo previo.

El carácter de respuesta apunta a una forma de institucionalización, a partir de la relación corresponsal, que implica un intercambio comunicativo y social y unas normas de comportamiento, pautadas en una forma genérica, identificada con la carta, aludida ya en el verso 1 como condición del poema. A partir de ahí se despliega la retórica de la epistolaridad, y lo hace desde la primera a la última palabra del poema. El arranque, «Hoy», no sólo supone una data; es una inequívoca referencia a un hic et nunc, que aleja todo el texto que sigue de cualquier pretensión de trascendencia, anclándolo en una realidad presente, la del día, vale decir, la de la cotidianidad. En el otro extremo del texto, la firma «Benegasi» ratifica el anclaje en la realidad: como hablante lírico y autor histórico, la referencia de este nombre propio disuelve la frontera entre realidad y ficción, entre vida práctica y espacio textual, proyectando el poema desde la intimidad de la comunicación privada al espacio público de la lectura de un texto impreso ${ }^{36}$. La caracterización del destinatario a partir del nombre, a lo que volveré más tarde, refuerza esta dialéctica, resaltando el componente literario y la clave estética que el texto adquiere en su realización tipográfica y editorial. De vuelta al componente de realidad ligado a la identificación del hablante con el autor, esta dimensión se ve reforzada, ya bien avanzado el texto, con un rasgo de confesionalismo, que introduce en el poema un nuevo elemento de verdad histórica. Entre los versos 169 y 172 el poeta ofrece una directa alusión a su situación vital, una viudedad de frecuente recurrencia en sus poemas, junto a la no menos citada vacilación en torno a su profesión religiosa. La confidencia (que ya no lo es en el espacio impreso) funciona retóricamente como un

36. Subraya el valor significativo de la firma P. Kamuf, Signature pieces: on the institution of authorship, Ithaca, Cornell University, 1988. Retomo y amplío la idea en mi estudio La rúbrica del poeta, ed. cit. 
elemento de convicción: el autor habla desde la realidad de la experiencia ${ }^{37}$, el caso concreto refuerza con el ejemplo la validez de las sentencias generales, y el rasgo de confianza hacia el receptor propicia en éste una actitud de correspondencia, abriéndose a los consejos de quien habla desde la asunción vital de una sabiduría y desnuda su pecho para ofrecer consejo. Estrategia suasoria, el recurso es también muy propio de la comunicación epistolar, hecha del entrecruzamiento de las noticias personales con las reflexiones de carácter general, entre la más estricta privacidad y el sentido de lo público que se deriva de la conversación, sobre todo esa conservación que se desarrolla en la distancia, se fija en la escritura y apunta a la publicación.

La retórica de la epistolaridad se hace expresa, tras el característico y programático exordio, a partir de la introducción de algo cercano a una figura correctionis entre los versos 2 y 24 . La referencia metapoética apunta, además, a una de las claves estilísticas del poema y al núcleo de la orientación de comportamiento que plantea, tanto en las palabras como en las obras (infra), con las significativas referencias al "pajarito» y al "grano». Tras ella comienza específicamente la narratio, que en este caso se traduce en la sucesión de consejos, a cuyo contenido habremos de volver. La insistencia en el uso de la segunda persona mantiene activa una situación de diálogo demorado, como respuesta a la demanda de consejo, siempre latente tras las palabras del corresponsal. El primer emisor se apunta en el rótulo inicial («uno») y se personaliza bien avanzado el texto (v. 114, en el ecuador exacto del poema), con la aparición de un nombre propio, propio en la forma, aunque común en la situación genérica. El «Fabio» de la apelación evoca el modelo que tiene en la epístola de Fernández de Andrada su realización suprema y su referencia para la posteridad ${ }^{38}$; no obstante, el contexto ya ha impuesto al lector que la situación ha cambiado al par que se ha ido desplazando la honda solemnidad de los tercetos del poema sevillano. Sólo ha habido que esperar al quinto verso para ver desmontado todo el aparato de la epístola moral a partir de sus propios componentes, los ligados a la figura de Fabio; en ese verso se reitera el sustantivo presente en el título, funcionando a modo de propositio en la estructura de la composición y, sobre todo, apuntando a un tono, el de la moralidad, también característico del género. Sin embargo, la rápida introducción del diminutivo, «consejitos», impone la clave de rebajamiento que el lector ya había podido percibir con el uso del metro de seguidillas en sustitución del molde canónico de la epístola moral. Con la renuncia a la trascendencia y la solemnidad, dinamitadas por el sufijo, se deja también de lado la amplitud de aliento propia del verso endecasílabo y la extensión de un género de epístolas que en la pluma de los Argensola, por ejemplo, superaba el número de 500 endecasílabos. La

37. Ya he apuntado el cambio de paradigma que se inicia a partir del empirismo inglés y se extiende por el sensismo hasta llegar a la ilustración. Véase también Paul Hazard, ob. cit.

38. Aunque la primera edición impresa de la Epistola moral no aparece hasta el Parnaso español (1768) de López de Sedano, no es de descartar que la tradición manuscrita (no menos de catorce testimonios documentados) hubiese asentado una cierta notoriedad de la pieza sevillana. 
urgencia de la vida práctica parece ser la que requiere la concisión, el lenguaje directo, esa brevedad a la que se apela en el verso 2 , con otro concepto de raíz gracianesca, en la que se insiste en los dos versos siguientes, para completar una conocida sentencia del aragonés. La carta alcanzará, ciertamente, una extensión apreciable, pero lo hará mediante el procedimiento de engarzar breves consejos o recomendaciones, apoyados en la estructura cuaternaria y de pie quebrado del verso de seguidilla, cuya combinación de heptasílabos y pentasílabos supera la agilidad prosódica del octosílabo; también su musicalidad, y ese particular ritmo de la seguidilla se impone como otra eficaz línea de negación de toda solemnidad, de vigencia de la jocosidad junto a los elementos más serios, como el del consejo y las reglas de gobierno.

La petición realizada inicialmente por el destinatario de la carta determina la pragmática de la respuesta, que sigue en esto con notable rigor las pautas del género. A ello responde el uso de los repetidos imperativos, que actualizan la presencia del interlocutor, pero también la del emisor que impone unas reglas o realiza desde su autoridad las indicaciones o consejos sobre el modo de comportarse. Entre las aplicaciones particulares se dibuja una difusa forma de regla general, más presente en la repetición de formas sentenciosas, aunque, como veremos después, la moralidad de orden universal se ve fuertemente condicionada por planteamientos más propios de la época y la clase que la protagonizaba. Para lo que sí vale este juego de consejos y reglas es para la actualización de una retórica basada en el ingenio conceptista, con agudezas hechas de dilogías y antítesis, de paradojas y quiebras del sentido previsto, con una clave gracianesca ya apuntada, en torno a la brevitas, pero también con referencias de mayor trascendencia en el plano del contenido, como cuando alude a las "palabras preñadas» (v. 97) y los «zahoríes de pensamiento» (vv. 99100 ), en claro aviso para el desarrollo de una prudencia que tiene mucho que ver con la disimulación, con el saber estar, pero traído del ámbito de la corte al del salón urbano. Porque el ingenio no sólo es cosa del pensamiento y la expresión, también del comportamiento o, como señalan los vv. 215-216, «que en obras y palabras / todo consiste». Siguiendo la Agudeza y arte de ingenio, se consideran en paralelo los conceptos de pensamiento y los de acción, y la referencia intelectual refuerza la evidencia del proyecto patente en el poemacarta: la actualización de los ideales de prudencia y discreción del jesuita, para aplicarlos, siguiendo su magisterio, al momento presente, a un gobierno que ya no corresponde a los planos en que se movía la moral altobarroca, con sus valores de trascendencia, sino a algo mucho más mundano, de tejas abajo, como imponía la sociabilidad del salón y del café, los nuevos escenarios de las relaciones sociales, junto a aquellos que tienen que ver con el comercio y el negocio.

Porque, ¿en qué es en lo que el nuevo sujeto que encarna el corresponsal debe «saberse gobernar»? ¿en qué obras y en qué palabras puede encontrar su identidad, su lugar en una sociedad que es la que define su ser como individuo? Comenzando por las obras, Benegasi introduce un sutil desplazamiento desde el horacianismo y su toque de estoicismo hacia las raíces de la ética aristotélica 
y su exaltación del justo medio, al que se apela desde prácticamente el inicio de la serie de «consejitos» (vv. 41-44), impregnando de esa máxima moral todo lo que viene a continuación, resaltando su sentido práctico. Así lo asienta la primera de las cuartetas en la serie de consejos, invirtiendo la formulación de los mandamientos divinos en el catecismo, ya que es en el arranque de los mandamientos humanos cuando éstos «se encierran en dos»: «El que siempre dos cosas / guardes prevengo: / la ley de Dios es una, / y otra, el dinero» (vv. 2528). Lo primero es, obviamente, una concesión a la moral tradicional, pues no queda ninguna referencia en ese sentido en los casi 200 versos restantes, todo lo contrario de lo que ocurre con el segundo de los principios, el económico. Diez versos después aparece la referencia a la moneda, y en el contexto de una casa y su economía; un pie similar da la recurrencia al dinero unos cien versos más adelante: "Al que debas y venga / cuando no hay blanca, / ya que no halle el dinero, / que te halle en casa» (vv. 141-144). La evocación de tratos y negocios se apoya en el campo semántico desplegado en la cuarteta precedente, con sus referencias a dar la palabra (apalabrar, hacer un contrato), a la fianza y la seguridad y a las fincas, esos valores inmuebles que, distanciándose del sentido feudal de la posesión de la tierra, van a sustentar el concepto capitalista de acumulación de riqueza y el sentido de la propiedad de la sociedad burguesa, en el ocaso del Antiguo Régimen.

En la misma línea se sitúa la proporcionalmente extensa referencia a la nobleza de la sangre (vv. 61-76), cuya validez se relativiza desde unas posiciones que, si bien tienen sus raíces en el humanismo renacentista y su fórmula del hombre como hijo de sus obras, se actualiza en la perspectiva de la quiebra de un régimen y la emergencia de un nuevo grupo social reclamando su protagonismo, un gobierno que comienza siendo el de la propia vida para ir buscando regir los destinos de la sociedad. Por muy tibio que aparezca en el poema, sus indicios nos remiten directamente a una realidad histórica, cuando los nobles de capa van siendo sustituidos en el gobierno por los manteístas, a cuyo socaire las ideas preilustradas empiezan a impulsar una economía de recuperación, en la que una nueva aristocracia urbana, la del negocio y el salón, se perfila frente a los viejos modelos. El cambio de ideales o, mejor dicho, la sustitución de las fantasías heroicas y caballerescas por un más práctico sentido de la realidad se manifiesta también en la prevención que la carta realiza respecto a uno de los elementos más característicos del género, las noticias. También apelando aquí al justo medio, el consejo rechaza las vulgaridades de las gacetas y las noticias del turco, entre la épica ilusa y un exotismo de pacotilla. Lo que debe regir el comportamiento del individuo en el nuevo marco social no es el interés por las relaciones de hechos ajenos, sino la atención a lo propio y específico, ese ámbito de lo particular, de lo privado, que constituye el gran descubrimiento o invención de la burguesía incipiente. La formulación es explícita en otro de los pasajes de recapitulación, justamente tras el rechazo de lo ajeno representado por las noticias. La conclusión es clara (vv. 185-188): «De modo que el cuidado / sólo se ponga / cada cual en aquello / que más le importa» ¿Dios o el dinero? El primer elemento del dilema no ha vuelto a aparecer en el texto, frente a 
las repetidas alusiones al segundo. Pero el silencio es aún más determinante, al remitir al juicio individual, a los criterios o intereses de cada uno, según el orden burgués. Aunque aún lejano, en el horizonte empieza a dibujarse el imperativo categórico kantiano como nueva norma ética, entre lo privado y lo público y, sobre todo, frente a toda moral de carácter heterónomo o dogmático. La carta entre amigos permite y propicia esta apelación a lo personal, que se traslada a una forma de consejo que sortea la moralidad tradicional y un «saberse gobernar» que remite a la vida práctica, característica del sujeto burgués ${ }^{39}$. Y unas y otras se apoyan en la conversación, esa forma de trato entre los individuos al margen de las jerarquías.

Las obras, así, conciertan con las palabras, y el comportamiento social se acompasa con el estilo, que le da forma y tono, componiendo en las conversaciones de salón la expresión última de una ética personal y un modelo de sociabilidad. La carta se cierra, en coherencia, con una serie de referencias al estilo, en simetría con los elementos de carácter metaliterario que abrían la misiva, antes de que ésta camine lenta a su final. Y, significativamente, la serie de recomendaciones se inicia con la práctica del verso, que arrastra una consideración de la poesía marcada por un signo de utilidad que ya no es el de la trascendencia altobarroca; más bien apunta al sentido práctico de los ilustrados, tal como Jovellanos recomendara a sus amigos de la tertulia salmantina. Junto a ellos se encuentra una nueva apelación al justo medio ${ }^{40}$, esta vez en el plano estilístico: entre lo culto y la degradación vulgar, se apunta a un mediocris stilus, hecho de llaneza expresiva, identificada con llamar a la cosas por su nombre, según la franqueza castellana, que llama al pan pan y (v. 207) a "la morcilla, morcilla» (recuérdese en este punto el motivo del romance epistolar que he numerado como 14 de la serie de las Obras líricas y jocoserias). Ahora bien, el mediocris stilus es también el resultado de la mezcla, de la combinación entre los sublimis y lo humilis o, dicho en otro modo, de lo serio y de lo jocoso, componiendo el estilo característico de la poesía más representativa del momento y el invocado por el propio Benegasi en el título de su libro ${ }^{41}$.

Las obras y las palabras (vv. 215 y 219-220) recomendadas apuntan en la misma dirección. Tras los consejos explícitos y la relación que los sustenta se abre el nuevo espacio de la urbanidad dieciochesca, labrada en el paulatino distanciamiento que desde el inicio del bajo barroco se percibe respeto a la

39. El ejemplo más acabado lo ofrece, sin duda, Francisco Gutiérrez de los Ríos, conde de Fernán Núñez, en El hombre práctico, o discursos varios sobre su conocimiento y enseñanzas (1686), ed. Jesús Pérez Magallón y Russell P. Sebold, Córdoba, Cajasur, 2000.

40. Véase, para el valor de este principio, José Checa Beltrán, Razones del buen gusto. Poética española del neoclasicismo, Madrid, CSIC, 1998; y Helmut Jacobs, Belleza y buen gusto: las teorias de las artes en la literatura española del siglo XVIII, Madrid, Iberoamericana, 2001.

41. A partir de sus ya citadas observaciones sobre el valor de lo burlesco en Góngora, Antonio Pérez Lasheras actualiza y concreta su perspectiva en Piedras preciosas... Otros aspectos de la poesía de Góngora, Universidad de Granada, 2009; y ahora en Ni amor ni constante. Góngora en su «Fábula de Píramo y Tisbe», Universidad de Valladolid, 2011. 
trascendencia y a la vida cortesana, ese correlato basado en la centralidad de un monarca y su imagen divina. Frente a ellos se impone la urbanidad en su doble sentido: de un lado, el que corresponde a la vida cotidiana, de ciudad, una existencia a ras de suelo, por más que en ella se trate de preservar una forma de brillo social; del otro lado, se apela a unas pautas de cumplimiento, de educación, de convivencia, que son las que, tras su convencionalidad, permiten ese brillo social, del que la poesía va a dar cuenta mientras es parte integrante de la misma, tocada por los mismos rasgos de artificiosa naturalidad, de trato conversacional, de sentido práctico bajo las formas aprendidas que caracterizaba la vida social desde el ocaso de los Austrias y, sobre todo, en los albores de la España borbónica. Y ésta es una de las dimensiones de la relación entre la poesía y la sociedad.

\section{Perspectiva y tentativa de Conclusiones}

Al situar lo observado en la epístola de Benegasi contra el horizonte de la dinámica histórica y su proyección en los avatares de un género, mientras se nos impone los cambios en la caracterización de la epístola poética, podemos percibir en su transformación un indicio de la dialéctica entre continuidad y cambio desarrollada en las décadas que siguen a la plenitud del alto barroco. El género ya había sido un indicador inequívoco de la superación del mundo renacentista, al registrar el desplazamiento del discurso humanista por el de la moral trascendente que tuvo en Trento su expresión más notoria. Como la cultura, la epístola en verso pasa del patrón humanista y horaciano al discurso de la moralidad, ajeno a cualquier forma de ambigüedad o de ironía, como la que latía en el amargo estertor del sueño del humanismo en la epístola de Lázaro de Tormes. Entre la subjetividad renacentista y el dogmatismo altobarroco, la epístola poética recupera con las últimas décadas del siglo XVII una nueva dialéctica entre la intimidad individual y la objetividad de lo real, entendido en su sentido más inmediato y presente. De la particularidad de la experiencia de que partían los continuadores de Boscán y Hurtado de Mendoza en España, hasta culminar en Aldana, quienes se sitúan en el entorno de la «Epístola satíricocensoria» de Quevedo, como ejemplo supremo del sentido sancionador de la moral (o la política), pasan al plano de lo general, convirtiendo la reflexión en lección y regla, de las que resultan el premio o la condena. Esta polaridad entra en quiebra en el bajo barroco, a partir de la deriva de los principios rectores de la ética y la poética que, hacia el ecuador del siglo, alcanzan la culminación en el Parnaso español de Quevedo y en la Agudeza y arte de ingenio de Gracián, pero también en su Criticón y su Comulgatorio.

Sobre una confesionalidad que había sustentado la reflexión humanista y el dictado barroco comienza a aflorar una tendencia a la convencionalidad, una máscara que entre las bromas de la jocosidad disimula los perfiles del rostro individual para acomodarlo a una práctica social donde van consolidándose las que se conocerán como las prácticas del buen gusto, hasta volver a unir 
bajo su égida el comportamiento burgués y la poética neoclásica e ilustrada. Hasta llegar al equilibrio de éstas, lo jocoso o, más precisamente, lo jocoserio ${ }^{42}$ contribuye a ese efecto, al borrar con la lima de la risa las asperezas de un compromiso personal muy acentuado o la trascendencia de una pretensión de valor universalizante. En paralelo, la fijación de la poesía en las páginas de un libro impreso, con su accesibilidad para un grupo abierto de lectores, desplaza los rasgos de la comunicación personal al plano más neutro de la dimensión pública o, por mejor decir, publicada, aunque reintegrando la comunicación poética a un plano de experiencia (de escritura o lectura) personal alejada de la teatralidad impuesta en la realización altobarroca.

La alteración del modelo genérico epistolar desde su formalización humanista a la altobarroca conlleva cambios estilísticos y pragmáticos importantes y apreciables. A la llaneza propia del ideal renacentista se contrapone (aunque sin llegar a los extremos de las formas más acentuadamente cultistas) un registro elevado, más acorde a la solemnidad de los valores transmitidos. También el marco cambia, ajustando el escenario a principios y modos: del locus amoenus (jardín, campo, retiro) la epístola se desplaza al ámbito cortesano como presencia casi ineludible, también cuando, en el tópico del menosprecio, se contrapone al ideal estoico o religioso que se aconseja ${ }^{43}$. La configuración del destinatario, finalmente, mantiene una estrecha relación con el resto de los componentes de la epístola en sus dos modelos; la relación entre amigos cultos es la que permite la ubicación de la correspondencia en el marco ideal del apartamiento ameno y el uso de un lenguaje sin afectación, mientras que la constitución del discípulo o puer representado por el emblemático Fabio remite a las amenazas de la vida cortesana e impone un tono de distanciamiento traducido en el hieratismo de un lenguaje elevado y solemne. En definitiva, se ponen en tensión dos polos que en todos sus ámbitos podemos sintetizar en la dialéctica entre cercanía y lejanía, entre la aproximación de la relación cordial y la distancia de un esquema de didactismo, entre los valores de los studia humanitatis y los principios de la teología y la antropología contrarreformistas.

Si ya el horacianismo de los Argensola representó una forma de conciliación entre la epístola moral y la formulación más clasicista, con una vigencia revitalizada a mediados del siglo XVII tras la publicación póstuma de las obras de los dos hermanos (1634), en líneas generales y, sobre todo, en lo que toca al plano genérico que nos ocupa, la segunda mitad de la centuria registró una creciente revisión de los modelos heredados, de la que lo jocoserio sólo es una de sus manifestaciones más evidentes. Conectando con lo más productivo

42. Analiza con clarividencia y rigor este concepto Jean-Pierre Étienvre, «Primores de lo jocoserio", Bulletin Hispanique, 106, 1, 2004, pp. 235-252.

43. Pese a su singularidad, son representativas a este respecto las dos composiciones de Pedro Espinosa conocidas como «epístolas a Heliodoro», dirigidas al duque de Medina Sidonia aconsejándole el retiro a la soledad. No es ajena a la naturaleza de estas piezas la condición de poeta-criado perseguida por el antequerano y mantenida a lo largo de las últimas décadas de su vida. La circunstancia es una muestra significativa del peso de las condiciones sociales (y económicas) y de los modelos de con/vivencia que producen. 
de la poética gongorina, la incorporación de un componente burlesco, de jocosidad, al discurso, aun cuando pudiera seguir formalmente unas pautas de continuidad, refleja la disolución paulatina del esquema de valores y principios que sustentaba la caracterización de los géneros ${ }^{44}$. Al compás de la crisis social que se ahonda al acercarse el final de siglo y de reinado, pierde valor actuante la conciencia de un «nosotros» de carácter moral o comunitario, que sustentaba, entre otras formas, la del discurso epistolar, donde "correspondencia» no sólo indica cruce de respuestas, también consonancia, comunidad. Mientras se reajusta el modelo (y no lo hará con cierta solidez hasta bien avanzado el reinado borbónico) se abre un espacio para la distancia, en la que lo jocoserio es la manifestación de una ironía que disuelve o, cuando menos, cuestiona la solidez del vínculo epistolar, como lo hacía con la celebración, la conmiseración o la crítica, propios de los contragéneros de la oda, la elegía y la sátira. Con el abandono de las formas y discursos correspondientes al nivel más culto y (neo) clásico, la poesía ahonda en los componentes del barroco mientras los reorienta, en una deriva que, hasta desembocar en la poética ilustrada, caracterizamos como del bajo barroco.

Según hemos visto culminar en el caso de Benegasi, ya casi al final de este proceso, la proyección de una deriva que no es mera continuidad ni cambio stricto sensu $u^{45}$ representa en el modelo de la epístola unas variaciones significativas, que pueden servirnos a la vez para caracterizar el modelo poético y su relación con el marco social. Siguiendo los elementos establecidos en la comparación entre la realización humanista y la barroca de la epístola, encontramos que ahora el estilo jocoso abre un nuevo espacio, donde se concitan la llaneza y una afectación no exenta de ironía. También entre el locus amoenus del retiro aldeano y la dignidad de la corte aparece un espacio intermedio, el urbano, al que remite el modelo de relaciones sociales establecido por los interlocutores. En él el amigo culto y el discípulo ceden su lugar al contertulio, un conocido con unas relaciones más convencionales que las derivadas del concepto humanista de amicitia; no es la intimidad confesional de dos espíritus en la misma sintonía la ahora presente, sino más bien un juego de relaciones convencionales, propias de la convivencia mundana, en las que incluso es posible asumir irónica y jocosamente un papel de consejero, como el que entre bromas y veras, actualizan las seguidillas de Benegasi.

Ni lejanía ni cercanía. Lo que se impone son las reglas de la urbanidad, las nuevas pautas de comportamiento social del ambiente urbano, del escenario de una burguesía ascendente, que pauta sus relaciones en una convencionalidad

44. Este avance en la más radical de la rupturas del cordobés es a mi juicio lo más neto de la continuidad del gongorismo, justamente aquello que aparta a la poesía del recargamiento ornamental y lo acerca a un tono de prosaísmo, el de los nuevos tiempos.

45. Mucho menos cabe hablar, como se ha simplificado, de una mera degeneración, en la línea de lo planteado por Sebold y su insistencia en un «ultrabarroquismo» del que sólo ofrece ejemplos aislados; véase, por ejemplo, La perduración de la modalidad clásica. Poesía y prosa españolas de los siglos XVII a XIX, Universidad de Salamanca, 2001, entre sus reiteradas páginas sobre el tema. 
educada pero distante, tal como el chichisbeo establecía para el juego entre los sexos. Con mucho de máscara y fingimiento, que desacraliza y desmitifica los grandes valores (amor, matrimonio, amistad, moral...), la urbanidad protoburguesa sublima sus tensiones y canaliza unas formas de expresión que responde a la configuración de un nuevo sujeto en un marco social en transformación. Así lo apreciamos en esa particular carta en seguidillas, con la defensa de los valores burgueses y el correspondiente registro estilístico. Teatralización de una conciencia de crisis (invirtiendo el concepto de Hazard), el poema de Benegasi contribuye a su formalización. Como él, la poesía del período que se extiende entre dos siglos no sólo reflejará en sus temas la realidad de sus transformaciones sociales. Con sus formas genéricas, su pragmática y su relectura de la tradición forman parte de este proceso y le ofrecen una vía de canalización. 